Review

\title{
Lung Cancer and Pulmonary Embolism: What Is the Relationship? A Review
}

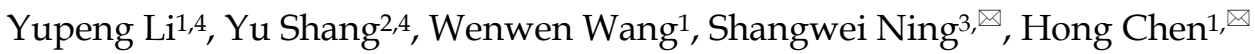 \\ 1. Department of Respiration, Second Affiliated Hospital of Harbin Medical University, Harbin 150081, China. \\ 2. Department of Respiration, First Hospital of Harbin, Harbin 150081, China. \\ 3. College of Bioinformatics Science and Technology, Harbin Medical University, Harbin 150081, China. \\ 4. Drs Yupeng Li and Yu Shang contribute equally to this article. \\ $\triangle$ Corresponding authors: Hong Chen, Phone: +86-451-86605736, Email: chenhong744563@aliyun.com. Shangwei Ning, Email: ningsw@ems.hrbmu.edu.cn.
}

(C) Ivyspring International Publisher. This is an open access article distributed under the terms of the Creative Commons Attribution (CC BY-NC) license (https://creativecommons.org/licenses/by-nc/4.0/). See http://ivyspring.com/terms for full terms and conditions.

Received: 2018.03.12; Accepted: 2018.06.08; Published: 2018.08.06

\begin{abstract}
Pulmonary embolism (PE) is gradually considered to be the third most common disease in the vascular disease category. Lung cancer is the most frequently diagnosed cancer and the leading cause of cancer death among males worldwide. Although initially appearing as distinct entities, lung cancer is a great risk factor for the development of PE. Pulmonary embolism is common in lung cancer patients, with a pooled incidence of 3.7\%, and unsuspected pulmonary embolism (UPE) is also non-negligible with a rough rate ranging from $29.4 \%$ to $63 \%$. Many risk factors of PE have been detected and could be classified into three categories: lung cancer-related, patient-related, and treatment-related factors. Decreased mean survival time could be significantly observed in lung cancer patients with PE or UPE compared to those only, but suspected PE has higher mortality than UPE. Prophylactic anticoagulant therapy benefit might be highest in patients with stage IV non-small cell lung cancer (NSCLC) or limited small cell lung cancer (SCLC), and heparin seems superior to warfarin for thrombotic prophylaxis. Periodically reassessing the risk-benefit ratio of anticoagulant treatment will be an efficient treatment strategy in lung cancer patients with PE.
\end{abstract}

Key words: Pulmonary embolism; Lung cancer; Venous thromboembolism; Non-small cell lung cancer; Small cell lung cancer

\section{Introduction}

It is generally recognized that cancer has a high risk of venous thromboembolism (VTE). Deep vein thrombosis (DVT) and pulmonary embolism (PE) are collectively referred to as venous thromboembolism. Notably, lung cancer, the most frequently diagnosed cancer and the leading cause of cancer death among males all over the world, and among females in more developed countries [1], is the most common malignancy coexisting in patients with pulmonary embolism [2,3], namely lung cancer is more prone to PE than other malignant tumors [4,5]. Undoubtedly lung cancer is a great risk factor for development of PE. For example, lung cancer patients are six times more likely to have a PE compared to cancer-free controls in the 12 months before diagnosis [6].

Indeed, PE plays an important role in the process of lung cancer as it affects the survival time of patients. Occurrence of PE is associated with decreased survival among lung cancer patients $[7,8]$ and evidences of pulmonary embolism as the cause of death have been reported in $10 \%$ of patients with lung cancer at the time of postmortem examination [9]. Furthermore, PE plays a significant role in healthcare utilization among lung cancer patients: evidences from VTE: the overall hospital charges were higher in lung cancer patients with VTE, at a mean of $\$ 43,800$ vs. $\$ 37,800$ for those without VTE $(p<0.001)[10]$ and the same trend was applicable to the ambulatory lung cancer patients with VTE $(\$ 28,003$ vs. $\$ 10,914$; P < $0.0001)$ [11]. Therefore, in this article, we provided an overview of this association between lung cancer and pulmonary embolism, and summarized incidence of PE, unsuspected pulmonary embolism, risk factors and pathophysiological considerations, treatment, 
prognostic significance as well as prophylaxis of thrombotic events.

\section{Table 1. Searched strategy for PubMed}

PubMed was searched from 1 January 1900 to 4 October 2017, using the following search strategy:

1. "Pulmonary embolism" [MeSH Terms:NoExp] OR lung embolism*[tiab] OR pulmonary embolism*[tiab] OR pulmonary thromboembolism*[tiab] $(n=47,689)$

2. "Lung Neoplasms"[MeSH:NoExp] OR lung carcinoma* [tiab] OR "Carcinoma,

Bronchogenic"[Mesh] OR Bronchogenic cancer* [tiab] OR Bronchogenic carcinoma*

[tiab] OR lung cancer* [tiab] OR pulmonary cancer* [tiab] OR pulmonary

carcinoma* [tiab] OR ("Adenocarcinoma, Bronchiolo-Alveolar"[Mesh] or lung

adenocarcinoma* [tiab] OR pulmonary adenocarcinoma* [tiab] or

Bronchiolo-Alveolar adenocarcinoma* [tiab]) OR (lung Squamous Carcinoma*

[tiab] OR pulmonary Squamous Carcinoma* [tiab) OR lung Large cell carcinoma

[tiab] OR adenosquamous carcinoma of the lung [tiab] $(\mathrm{n}=241,235)$

3. "1900/01/01"[pdat] : "2017/10/04"[pdat] $(\mathrm{n}=27,711,426)$

4. 1 AND 2 AND $3(n=1,236)$

5. Review[ptyp] OR letter[ptyp] OR editorial[ptyp] OR case reports[ptyp] (n = $5,267,472)$

6. 4 NOT $5(n=635)$

\section{Methods}

Publications were identified through searching the PubMed from 1, 1900 to October 4, 2017. The search was supplemented by a manual search of published reviews and the strategy was designed and constructed by authors (Table 1). We excluded studies having less than five original cases as well as without interesting outcomes according to screen the abstract whereas we included the cohort of patients enrolled in randomized controlled trials (RCTs), as we want to find out the incidences of pulmonary embolism in all kinds of clinical trials. Overall, we screened abstracts of articles obtained through PubMed search and hand-searched the reference list of pertinent articles. Two authors (Y.P.L and Y.S) independently screened the titles and abstracts of the identified articles and they extracted and interpreted the data independently, then in duplicate.

\section{Incidence of PE in Lung Cancer Patients}

The incidence of PE is flexible in various studies, thereby we searched the dates about incidence of PE in patients with lung cancer, hoping to summarize an overall incidence of PE. According to the full-text paper screening, forty-one studies consisting of 13 RCTs [12-24], 27 retrospective cohorts [11, 25-50], 1 prospective cohort [51] had been selected and showed in table 2.

Table 2. Coexisting PE reported in patients with lung cancer.

\begin{tabular}{|c|c|c|c|c|c|c|c|c|c|c|}
\hline First author, year & $\begin{array}{l}\text { Population } \\
\text { description }\end{array}$ & Study design & $\begin{array}{l}\text { Total } \\
\mathrm{N}\end{array}$ & $\mathrm{PE}, \mathrm{n}(\%)$ & $\begin{array}{l}\text { Type of } \\
\text { lung } \\
\text { cancer }\end{array}$ & $\begin{array}{l}\text { NSCLC, } \\
\mathrm{n}\end{array}$ & Number of stages (\%) & $\begin{array}{l}\text { Age, Years, } \\
\text { Mean (range) }\end{array}$ & $\begin{array}{l}\text { No. of male } \\
(\%)\end{array}$ & Country of Origin \\
\hline Wehler [12], 2017 & Nonsurgical & RCT & 62 & $5(8.0)$ & NSCLC & 62 & $\mathrm{IV}=62$ & NR & NR & Germany and Spain \\
\hline Moon [25], 2017 & Surgical & Retrospective & 1,196 & $33(2.7)$ & NR & NR & NR & NR & NR & Korea \\
\hline Fred [13], 2017 & Nonsurgical & $\mathrm{RCT}$ & 106 & $3(3.0)$ & NSCLC & 106 & NR & $67(42-84)$ & $79(72)$ & Unite States et al. \\
\hline Levy [14], 2016 & Nonsurgical & $\mathrm{RCT}$ & 16 & $1(6.0)$ & NSCLC & 16 & $\mathrm{IIIB}=16$ & $55.5(43-70)$ & $12(75)$ & France \\
\hline Goss [15], 2016 & Nonsurgical & RCT & 199 & $7(3.0)$ & NSCLC & 199 & NR & $64(35-88)$ & $64(32)$ & Canada et al. \\
\hline Glover [26], 2016 & Surgical & Retrospective & 52 & $1(2.0)$ & NSCLC & 52 & $\begin{array}{l}\mathrm{II}=11(21), \mathrm{III}=36(69), \mathrm{IV}= \\
5(10)\end{array}$ & $67.2(48.0-86.0)$ & $30(57.7)$ & Unite States \\
\hline Mungo [27], 2016 & Surgical & Retrospective & 133 & $0(0)$ & NSCLC & 133 & $\mathrm{I}=126(94.7), \mathrm{II}+\mathrm{III}=7(5.3)$ & $66.7(60-74)$ & NR & Unite States \\
\hline $\begin{array}{l}\text { Michelsen [28], } \\
2015\end{array}$ & Nonsurgical & Retrospective & 42 & $5(11.9)$ & NSCLC & 42 & $\mathrm{IIIB}=2(4.8), \mathrm{IV}=40(95.2)$ & $62(23-74)$ & $17(40.5)$ & Denmark \\
\hline Sandri [29], 2015 & Surgical & Retrospective & 227 & $2(0.9)$ & NR & NR & NR & 67.9 & $106(47)$ & United Kingdom \\
\hline $\mathrm{Hu}$ [16], 2015 & Nonsurgical & RCT & 56 & $12(21.4)$ & NSCLC & 56 & NR & $59.6(32-83)$ & $31(55.4)$ & China \\
\hline Cukic [30], 2015 & $\begin{array}{l}\text { Nonsurgical } \\
+ \text { Surgical }\end{array}$ & Retrospective & 1,609 & $42(2.6)$ & $\begin{array}{l}\text { NSCLC } \\
+ \text { SCLC }\end{array}$ & NR & NR & NR & NR & $\begin{array}{l}\text { Bosnia and } \\
\text { Herzegovina }\end{array}$ \\
\hline Verso [31], 2015 & NR & Retrospective & 173 & $41(23.7)$ & NSCLC & 173 & $\begin{array}{l}\text { IIIB }=18(10.4), \text { IV = } 155 \\
(89.6)\end{array}$ & 62.4 & $104(60.1)$ & Italy \\
\hline $\begin{array}{l}\text { Karavasilis [17], } \\
2014\end{array}$ & Nonsurgical & RCT & 50 & $1(2.0)$ & NSCLC & 50 & NR & $62.5(43-74)$ & $39(78)$ & Greece \\
\hline $\begin{array}{l}\text { Zhang Y [32], } \\
2014\end{array}$ & Nonsurgical & Retrospective & 673 & $47(7.0)$ & $\begin{array}{l}\text { NSCLC } \\
+ \text { SCLC }\end{array}$ & 565 & NR & 64 & $486(72.2)$ & China \\
\hline $\begin{array}{l}\text { Dingemans [18], } \\
2014\end{array}$ & Nonsurgical & RCT & 25 & $1(4.0)$ & NSCLC & 25 & $\mathrm{III}=25$ & $59(45-72)$ & $12(48)$ & Belgium \\
\hline $\begin{array}{l}\text { Mellema [33], } \\
2014\end{array}$ & Nonsurgical & Retrospective & 784 & $25(3.2)$ & NSCLC & 784 & $\begin{array}{l}\mathrm{I}-\mathrm{IIB}=42(5.4), \mathrm{IIIA}=197 \\
(25.1), \mathrm{IIIB}=199(25.4), \mathrm{IV}= \\
346(44.1)\end{array}$ & $59.5 \pm 10.6$ & $504(64.3)$ & Netherlands \\
\hline Wang [34], 2014 & Surgical & Retrospective & 525 & $1(0.2)$ & NR & NR & $\mathrm{I}=321(61.4), \mathrm{II}=204(38.9)$ & NR & $289(55.0)$ & China \\
\hline Kadlec [35], 2014 & $\begin{array}{l}\text { Nonsurgical } \\
+ \text { Surgical }\end{array}$ & Retrospective & 950 & $34(3.6)$ & $\begin{array}{l}\text { NSCLC } \\
+ \text { SCLC }\end{array}$ & 662 & $\begin{array}{l}\mathrm{I}=80(8.4), \mathrm{II}=76(8), \mathrm{III}= \\
274(28.8), \mathrm{IV}=393(41.4) \\
\text { Unknown = } 127(13.4)\end{array}$ & 64 & $600(63.2)$ & Czech Republic \\
\hline $\begin{array}{l}\text { Nguyen [36], } \\
2013\end{array}$ & Nonsurgical & Retrospective & 9 & $1(11.0)$ & SCLC & 0 & $\mathrm{IIIA}=6$ (66.7), IIIB = 3 (33.3) & $60(46-84)$ & $7(77.8)$ & Unite States \\
\hline Yu [37], 2013 & Surgical & Retrospective & 21 & $0(0)$ & NSCLC & 21 & NR & $56.4 \pm 3.6$ & $15(71.4)$ & China \\
\hline Luo [38], 2013 & $\begin{array}{l}\text { Nonsurgical } \\
+ \text { surgical }\end{array}$ & Retrospective & 52 & $0(0)$ & $\begin{array}{l}\text { NSCLC } \\
+ \text { SCLC }\end{array}$ & 24 & $\mathrm{III}=33(63.5), \mathrm{IV}=19(36.5)$ & $65(42-75)$ & $41(78.8)$ & China \\
\hline Powell [19], 2013 & Nonsurgical & $\mathrm{RCT}$ & 42 & $1(2.4)$ & NSCLC & 42 & $\mathrm{IIIB}=3(7.1), \mathrm{IV}=39(92.8)$ & $62.5(36-80)$ & $18(42.9)$ & Unite States \\
\hline Connolly [39], & Nonsurgical & Retrospective & 207 & $17(8.2)$ & NSCLC & 193 & $\mathrm{I}=61(29.4), \mathrm{II}=16(7.7), \mathrm{III}=$ & $66(28-89)$ & $92(44)$ & Unite States \\
\hline
\end{tabular}




\begin{tabular}{|c|c|c|c|c|c|c|c|c|c|c|}
\hline First author, year & $\begin{array}{l}\text { Population } \\
\text { description }\end{array}$ & Study design & $\begin{array}{l}\text { Total } \\
\mathrm{N}\end{array}$ & PE, n (\%) & $\begin{array}{l}\text { Type of } \\
\text { lung } \\
\text { cancer }\end{array}$ & $\begin{array}{l}\text { NSCLC, } \\
\mathrm{n}\end{array}$ & Number of stages (\%) & $\begin{array}{l}\text { Age, Years, } \\
\text { Mean (range) }\end{array}$ & $\begin{array}{l}\text { No. of male } \\
(\%)\end{array}$ & Country of Origin \\
\hline 2013 & + Surgical & & & & +SCLC & & $\begin{array}{l}33(15.9), \text { IV = 91 (43.9), } \\
\text { Unknown = } 6(2.9)\end{array}$ & & & \\
\hline Crolow [40], 2013 & NR & Retrospective & 1,940 & $98(5.0)$ & $\begin{array}{l}\text { NSCLC } \\
+ \text { SCLC }\end{array}$ & 1,784 & $\begin{array}{l}\mathrm{I}=334(17), \mathrm{II}=206(11), \mathrm{III}= \\
547(28), \mathrm{IV}=818(42) \\
\text { Unknown = } 35(2)\end{array}$ & $66(19-93)$ & $1,209(62)$ & Germany \\
\hline Dhakal [41], 2013 & Surgical & Retrospective & 320 & $4(1.25)$ & NSCLC & 320 & NR & $67(25-88)$ & $135(42.2)$ & Unite States \\
\hline $\begin{array}{l}\text { Mountzios [20], } \\
2012\end{array}$ & Nonsurgical & $\mathrm{RCT}$ & 30 & $1(3.3)$ & SCLC & 0 & NR & $64(43-82)$ & $27(90)$ & Greece \\
\hline $\begin{array}{l}\text { Shinagare [42], } \\
2012\end{array}$ & NR & Retrospective & 2,262 & $77(3.4)$ & NR & NR & NR & NR & NR & Unite States \\
\hline $\begin{array}{l}\text { Connolly [11] } \\
2012\end{array}$ & Nonsurgical & Retrospective & 6,732 & $441(6.5)$ & NR & NR & NR & 63.6 & $3,329(49.5)$ & Unite States \\
\hline Sun JM [50], 2010 & $\begin{array}{l}\text { Nonsurgical } \\
+ \text { Surgical }\end{array}$ & Retrospective & 8,014 & $180(2.2)$ & $\begin{array}{l}\text { NSCLC } \\
+ \text { SCLC }\end{array}$ & 7,272 & $\begin{array}{l}\mathrm{IV}=3,494(43), \mathrm{I}-\mathrm{III}=4,075 \\
(51), \text { Unknown }=445(6)\end{array}$ & NR & $5,784(72)$ & Republic of Korea \\
\hline Crinò [21], 2010 & Nonsurgical & RCT & 2,212 & $30(1.3)$ & NSCLC & 2,212 & $\mathrm{IIIB}=436(20), \mathrm{IV}=1,775(80)$ & $58.8(24-86)$ & $1,329(60)$ & Italy \\
\hline Altorki [22], 2010 & $\begin{array}{l}\text { Nonsurgical } \\
+ \text { surgical }\end{array}$ & $\mathrm{RCT}$ & 35 & $1(2.8)$ & NSCLC & 35 & $\begin{array}{l}\mathrm{IA}=19(54), \mathrm{IB}=14(40), \mathrm{IIA} \\
=1(3), \mathrm{IIB}=1(3)\end{array}$ & $64(49-81)$ & $13(37.1)$ & Unite States \\
\hline Dentali [43], 2008 & Surgical & Retrospective & 693 & $9(1.3)$ & NR & NR & NR & $66.7(23-90)$ & $418(60.6)$ & Italy \\
\hline $\begin{array}{l}\text { Numico [51] } \\
2005\end{array}$ & Nonsurgical & Prospective & 108 & $3(2.8)$ & NSCLC & 108 & $\mathrm{III}=41(38.0), \mathrm{IV}=67(52.0)$ & $63.6(38-76)$ & $87(80.5)$ & Italy \\
\hline $\begin{array}{l}\text { Behrendt [44], } \\
2003\end{array}$ & Nonsurgical & Retrospective & 1,023 & $31(3.0)$ & NSCLC & 1,023 & $\begin{array}{l}\text { IV = } 687(67.3), \text { recurrent }= \\
120(11.8), \mathrm{IIIB}=213(20.9)\end{array}$ & $66.1 \pm 10.0$ & $665(65.0)$ & Unite States \\
\hline G. F [45], 2003 & Surgical & Retrospective & 179 & $2(1.1)$ & NSCLC & 179 & $\mathrm{IA}=118(65.9), \mathrm{IB}=61$ (34.1) & $64.3(38-87)$ & $88(49.1)$ & Unite States \\
\hline $\begin{array}{l}\text { Sakuragi [46], } \\
2003\end{array}$ & Surgical & Retrospective & 372 & $7(1.9)$ & NR & NR & NR & NR & NR & Japan \\
\hline S. M [47], 2000 & $\begin{array}{l}\text { Nonsurgical } \\
+ \text { Surgical }\end{array}$ & Retrospective & 23 & $1(4.3)$ & NSCLC & 23 & NR & 53 & $12(52.1)$ & Unite States \\
\hline Levitan [23], 1998 & Nonsurgical & $\mathrm{RCT}$ & 30 & $2(6.0)$ & NSCLC & 30 & $\mathrm{IIIB}=10(33), \mathrm{IV}=20(67)$ & $64(41-74)$ & $18(60)$ & Unite States \\
\hline $\begin{array}{l}\text { Fanucchi [24], } \\
1997\end{array}$ & Nonsurgical & $\mathrm{RCT}$ & 40 & $1(2.5)$ & NSCLC & 40 & $\mathrm{III}=20(50), \mathrm{IV}=20(50)$ & $58(32-78)$ & $27(68)$ & Unite States \\
\hline $\begin{array}{l}\text { Tavecchio [48], } \\
1994\end{array}$ & $\begin{array}{l}\text { Nonsurgical } \\
+ \text { Surgical }\end{array}$ & Retrospective & 57 & $2(3.5)$ & $\begin{array}{l}\text { NSCLC } \\
+ \text { SCLC }\end{array}$ & 51 & $\begin{array}{l}\text { IIIA = } 19(33.3), \text { IIIB = } 38 \\
(66.7)\end{array}$ & $56(46-70)$ & $53(92.9)$ & Italy \\
\hline Thomas [49], 1994 & $\begin{array}{l}\text { Nonsurgical } \\
+ \text { Surgical }\end{array}$ & Retrospective & 15 & $2(13.3)$ & $\begin{array}{l}\text { NSCLC } \\
+ \text { SCLC }\end{array}$ & 14 & $\begin{array}{l}\mathrm{IIIA}=2(13.3), \mathrm{IIIB}=11 \\
(73.4), \mathrm{IV}=2(13.3)\end{array}$ & $58(33-71)$ & $14(93.3)$ & France \\
\hline
\end{tabular}

NOTE: NR: not reported; VTE: venous thromboembolism; PE: pulmonary embolism; RCT: randomized controlled trial; NSCLC: non-small cell lung cancer; SCLC: small cell lung cancer.

PE is a frequent finding, with an overall incidence of $3.7 \%$ (1,172 of 31,294), ranging from 0 to $23.7 \%$ in lung cancer patients [11-51]. The pooled frequency of PE in RCTs is $2.3 \%$ (66 of 2,903), ranging from $1.3 \%$ to $21.4 \%$ [12-24], of all the highest rate $(21.4 \%)$ of PE occur in the process of chemotherapy where nab-paclitaxel was used to treat patients with advanced NSCLC who failed first-line chemotherapy [16] followed by $8 \%$ in a RCT for the evaluation of pemetrexed plus cisplatin in combination with or without LY2603618 (a selective checkpoint kinase 1 inhibitor) in patients with advanced nonsquamous NSCLC [12], impling the incidence of PE in various RCTs for lung cancer patients could be high. The PE rate is lower in lung cancer patients only undergoing lung resection $(1.6 \%, 59$ of 3,718, range: $0-2.7 \%)$ [25-27, $29,34,37,41,43,45,46]$ than those only receiving nonsurgical therapy $(5.0 \%, 618$ of 12,239 , range: $1.3 \%-21.4 \%$ ) [11-21, 23, 24, 28, 32, 33, 36, 44, 51], yet than those receiving comprehensive therapy (surgical and nonsurgical) $(2.5 \%, 279$ of 10,962, range: $0-13.3 \%)$ $[22,30,35,38,39,47-50]$. These results imply that the risk of $\mathrm{PE}$ in lung cancer patients receiving nonsurgical therapy is higher than those only undergoing lung resection. Furthermore, the overall frequency of $\mathrm{PE}$ in patients undergoing video-assisted thoracoscopic surgery (VATS) or robotic-assisted video thoracoscopic surgery (RAVTS) for lung cancer is $0.5 \%$ varying between 0 and $2 \%[26,27,29,34,37$, $45]$, implying VATS or RAVTS is feasible in lung cancer.

The majority of patients were male $(15,754$, $61.4 \%$ ) and the mean age was 62.5 years, ranging from 19 to 93 [11, 13-24, 26, 28, 29, 31-41, 43-45, 47-51]. We also found that major patients only receiving surgery for lung cancer had stage I/II but those receiving nonsurgical conditions had stage III/IV according to table 2, which might be one of causes of higher rate of $\mathrm{PE}$ in lung cancer patients with nonsurgical therapy.

In a review of lung cancer patients undergoing lung resection [7], despite whether the patients underwent chemotherapy or radiotherapy or both, the overall frequency of PE in 10,660 patients was $1.2 \%$ (slightly lower than our finding), and Christensen and colleagues also found the mean risk of $\mathrm{PE}$ was $1.8 \%$ in lung cancer patients where antithrombotic prophylaxis was used.

\section{Unsuspected Pulmonary Embolism}

Many lung cancer-associated PE events are found incidentally on radiographic testing performed for diagnostic or staging purposes and treatment response evaluation to lung cancer patients, which has been described as unsuspected pulmonary 
embolism (UPE). In several studies, 29.4\%, 37.5\%, $40 \%, 63 \%$ of PE in lung cancer patients are respectively and incidentally diagnosed $[8,39,50,52]$. And the performances of imaging are very contrastive: suspected PE more commonly involves main/lobar pulmonary arteries $(73 \%$ versus $28 \%$, $p=$ 0.0001 ) whereas UPE more frequently involves segmental arteries (38\% vs. $11 \%, \mathrm{p}=0.01)$ [42]. Besides, adenocarcinoma and frequency of anti-cancer therapeutic agents are more common in the clinically unsuspected group, conversely, squamous cell carcinoma is more common in the clinically suspected group ( $24 \%$ versus $0 \%, p=0.002)$. However, age, presence of metastatic disease, gender at the time of PE or treatment for PE are similar in the both groups [42].

\section{Risk Factors and Pathophysiological Considerations}

PE resulted from a combination of the following: vascular endothelial damage, stasis of blood flow, and hypercoagulability. These factors appear to be present in lung cancer patients and can be classified as: lung cancer-related, patient-related and treatment-related factors (Fig. 1).

\subsection{Hypercoagulability}

Both Intrinsic pathway (INTEM) and extrinsic pathway (EXTEM) participate in coagulation. Hypercoagulability have been described for an imbalance between procoagulant and anticoagulant factors and could contribute to pulmonary embolism in patients with lung cancer. Studies have uncovered some risk factors in patients with lung cancer that can contribute to the hypercoagulability, including decreased clot formation time (both in INTEM and EXTEM), elevated maximum clot firmness and alpha angle, higher levels of fibrinogen and platelets [53] as well as increased prothrombin fragment $1+2$ (F $1+2$; a marker of thrombin generation) and thrombinactivatable fibrinolysis inhibitor immunologic activity level (inhibition of the fibrinolytic system) [54]. Tissue factor (TF), the initiator of the clotting cascade, over expresses in lung cancer cells, which implies that TF is an activator of coagulation in the wide array of lung cancer cells [55]. In addition, platelets after chemotherapy had elevated PCA (procoagulant activity) and may contribute to the hypercoagulability of non-small cell lung cancer (NSCLC) [56].

\subsection{Lung Cancer-Related Risk Factors}

\subsubsection{Histological type}

Multivariate analysis finds NSCLC is at high risk of $\mathrm{PE}$ in lung cancer patients (OR, 2.88; 95\% CI: 1.97-3.78, $\mathrm{p}=0.008$ ) [57]. In particular, adenocarcinoma, one of subtypes of NSCLC, is an independent risk factor for development of $\mathrm{PE}$ in lung cancer patients [32, 58-61]. Both platelet activation and thrombin generation processes could contribute to

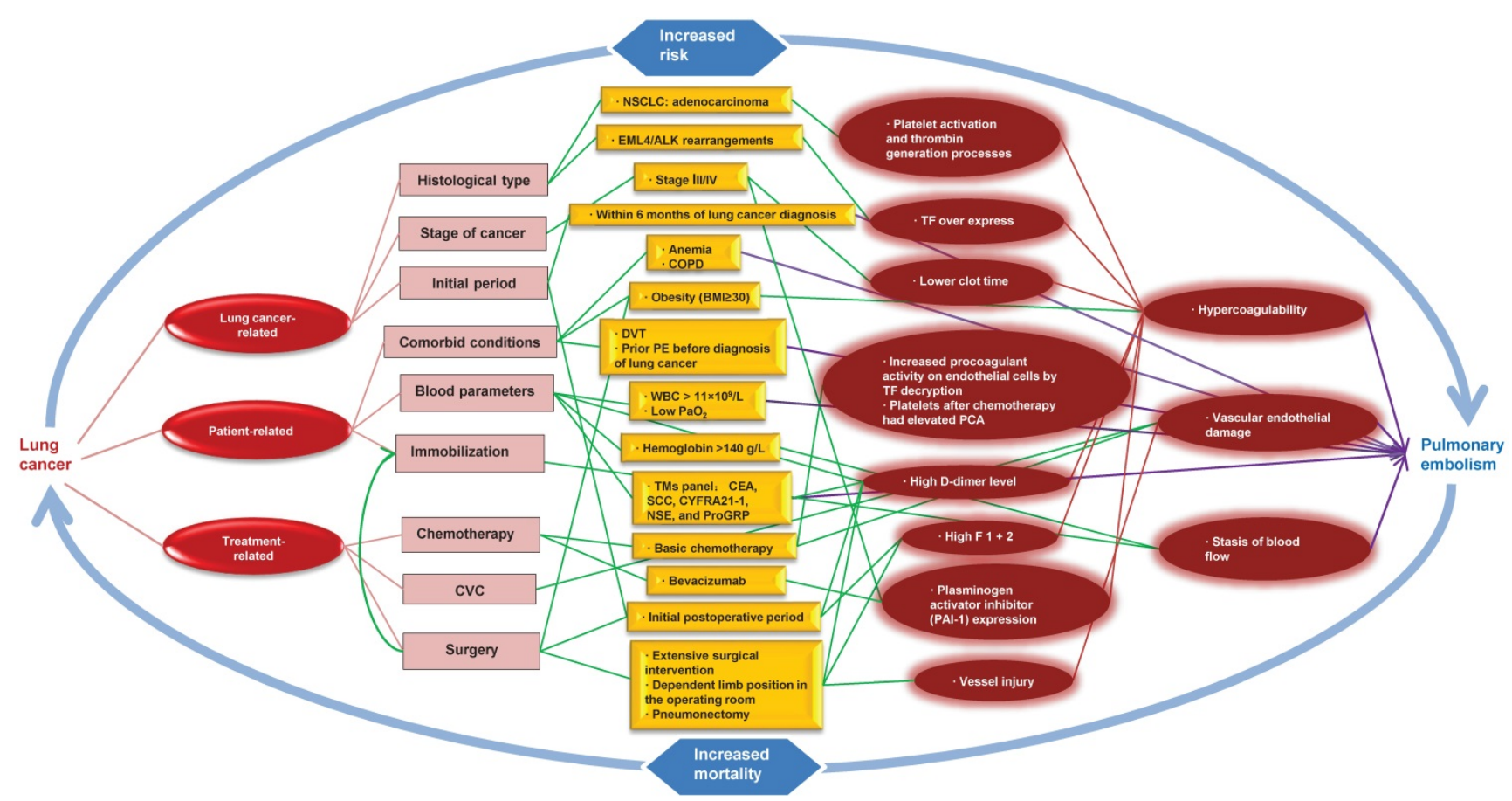

Fig. 1. Pathophysiological link between lung cancer and pulmonary embolism. NOTE: CVC: central venous catheters; CEA: serum carcinoembryonic antigen; WBC: white blood cell; COPD: chronic obstructive pulmonary disease; DVT: deep vein thrombosis; PE: pulmonary embolism; PCA: procoagulant activity; TF: tissue factor; F 1 + 2: prothrombin fragment 1 + 2; BMI: body mass index; NSCLC: non-small cell lung cancer; SCC: squamous cell carcinoma antigen; CYFRA21-1: cytokeratin 19 fragment; NSE: neuron-specific enolase; ProGRP: progastrin-releasing peptide; TMs: tumor markers. 
blood hypercoagulability according to lead to the expression of procoagulant phospholipids and the release of phosphatidylserine expressing microparticles in primary non-metastatic localized lung adenocarcinoma [62].

\subsubsection{Stage of lung cancer}

Advanced stage (stage III to IV) at initial diagnosis of lung cancer is an independent risk factor associated with PE [59, 63]. Another study also confirmed that stage IV or extensive disease (stage of SCLC) is independent risk factors of PE (OR, 1.9; 95\% CI: 1.4-2.6, p < 0.001) [50]. Furthermore, in univariate analysis, brain or leptomeningeal metastasis are associated with a significant higher risk of PE in lung cancer patients $(\mathrm{p}<0.001)$ whereas in multivariate analysis, the association seems to be weak (OR, 1.4; 95\% CI: 0.98-2.0, $\mathrm{p}=0.06$ ) [50]. Lung cancer patients with stage III/IV have lower clot time and higher plasminogen activator inhibitor (PAI-1) level compared to those with stage I/II $(\mathrm{p}<0.05)$ [53], which could be the cause of higher risk of PE in lung cancer patients with stage III/IV.

\subsubsection{Other risk factors}

The highest incidence of PE occurs within 6 months of the diagnosis of lung cancer (hazard ratio [HR], 16.8; 95\% CI: 7.6-36.8; after adjustment for antihypertensive drugs), thereafter, the risk falls (HR, 5.1; 95 \% CI: 2.7-9.4) [6]. In terms of three oncogene drivers: EGFR (epidermal growth factor receptor) mutations, KRAS (KRAS proto-oncogene, GTPase) mutations and EML4/ALK (ALK receptor tyrosine kinase) rearrangements in lung cancer patients, the presence of EML4/ALK rearrangements is associated with a 2-fold high risk of PE (HR, 2.06; 95\% CI: 1.08-3.55) whereas risk of PE is not found to be associated with EGFR or KRAS mutations [31]. Indeed, ELM4/ALK rearrangements lead to expression of a potent tyrosine kinase that is able to enhance the TF procoagulant activity [64, 65].

\subsection{Patient-Related Risk Factors}

\subsubsection{Comorbid conditions}

Studies have uncovered some comorbid conditions in patients with lung cancer that can contribute to the development of $\mathrm{PE}$, including anemia (Hemoglobin $\leq 100 \mathrm{~g} / \mathrm{L}$ ) $[32,58,66]$, obesity [body mass index $(\mathrm{BMI}) \geq 30$ ] among patients with primary lung cancer undergoing lobectomy $(1.5 \%$ vs. $0.8 \%, \mathrm{P}=0.005)$ [67], chronic obstructive pulmonary disease (COPD) [63] and DVT (OR, 10.62; 95\% CI: 4.94-18.08, $\mathrm{p}<0.001$ ) [57]. However, $\mathrm{Ma}$ et al. suggested that comorbidities such as diabetes, hypertension, pulmonary tuberculosis and cardiovascular disease were not risk factors of PE in patients with lung cancer $(p>0.05)$ [59].

\subsubsection{Blood parameters}

Multivariate analysis indicates that serum hemoglobin $>140 \mathrm{~g} / \mathrm{L}$ is at high risk for development of $\mathrm{PE}$ in lung cancer patients (OR, 2.10; 95\% CI: 1.44-3.08, $\mathrm{p}=0.03$ ), which could result from stasis of blood flow due to higher blood viscosity [63]. In addition, white blood cell (WBC) > 11×10\%/L, D-dimer > $500 \mu \mathrm{g} / \mathrm{L}$ (OR, 3.15; 95\% CI: 2.044-3.863, p $=0.025), \mathrm{PaO}_{2}<80 \mathrm{mmHg}$ are respectively the independent risk factors of $\mathrm{PE}$ in lung cancer patients [58]. Another two studies also show that different D-dimer levels $(865 \pm 489 \mu \mathrm{g} / \mathrm{L}, \mathrm{OR}=2.7$ or $2,670 \pm$ $1,350 \mu \mathrm{g} / \mathrm{L}, \mathrm{OR}=6.16$ ) are independent risk factors of PE $[57,59]$, which implies the D-dimer level could be positively associated with the risk of PE.

In terms of tumor markers (TMs) panel: carcinoembryonic antigen (CEA), squamous cell carcinoma antigen (SCC), cytokeratin 19 fragment (CYFRA21-1), neuron-specific enolase (NSE) and progastrin-releasing peptide (ProGRP), the multivariate logistic analysis demonstrates that TMs panel (OR, 5.98; 95\% CI: 2.36-9.04, $\mathrm{P}<0.001$ ) has significant correlation with $\mathrm{PE}$ and the AUC (area under curve) is 0.82 (95\% CI: 0.71-0.95, $\mathrm{P}<0.001$ ) according to ROC (receiver operating characteristic) curve analysis, meanwhile, not less than 3 abnormal values in the five TMs is the optimal cutoff value to assist the diagnosis of PE with both high sensitivity and specificity $(81.6 \%$ and $83.8 \%$, respectively) [57]. For individual TMs, CEA is the most relevant one with PE and the AUC is 0.71 or 0.68 according to ROC curve analysis $[32,57]$. The number of abnormal TMs is positive correlation of D-dimer level ( $\mathrm{P}$ trend < 0.001) in lung cancer patients with PE, the same trend is applicable to CEA $\left(\mathrm{R}^{2}=0.735, \mathrm{P}=0.003\right)$ and CYFRA21-1 $\left(\mathrm{R}^{2}=0.718, \mathrm{P}=0.005\right)$ [57], which could contribute to the development of PE.

\subsubsection{Other risk factors}

Immobilization could contribute to the development of PE in lung cancer patients [68] according to lead to stasis of blood flow. In addition, female sex is also associated with a significantly higher risk of PE in lung cancer patients ( $p<0.0001)$ according to univariate analysis whereas in multivariate analysis, the association seems to be weak (OR, 1.2; 95\% CI: 0.9-1.7, $\mathrm{p}=0.2$ ) [50]. Moreover, hospitalization in the 12 months before diagnosis of lung cancer is remarkably correlated with occurrence of PE after diagnosis (HR, 50; 95\% CI: 12-203; after adjustment for age and gender) [6]. Although smoking is associated with development of PE in 
general population, it is not a risk factor of PE in lung cancer patients $[57,59,63]$.

\subsection{Treatment-Related Risk Factors}

\subsubsection{Surgery}

Surgery is associated with increased risk of PE in lung cancer patients (OR, 4.33; 95\% CI: 2.36-4.92, p < 0.001) [57] even in patients receiving antithrombotic prophylaxis, there seems to be a substantial risk of PE $[29,43]$. The results suggest that despite thromboprophylaxis, surgery is an important risk factor of PE in lung cancer patients. Furthermore, the risk of PE developing within the first month postoperatively is $1.3 \%$, similar to $1.1 \%$ after 1 month of observation time, which could indicate that $\mathrm{PE}$ predominantly occurs within the initial postoperative period, and subsequently the risk falls [7]. Increased hypercoagulability (elevated D-dimer level and F1 + 2 concentrations) within the first 9-10 postoperative days $[69,70]$ could contribute to the development of PE in NSCLC patients.

Increased risk of pulmonary embolism in patients undergoing surgery for lung cancer involve extensive surgical intervention, the intrinsic procoagulant effect of lung cancer, vessel injury due to the operation, and dependent limb position in the operating room [43]. In addition, lung cancer patients undergoing pneumonectomy are at higher risk of PE than those having lobectomy or segmental resection and massive pulmonary embolism is a frequent early postoperative fatal complication after lung resections, which can't be safely prevented by postoperative heparinization [71].

\subsubsection{Chemotherapy}

Chemotherapy is an independent risk factor for the development of PE in lung cancer patient (OR, 2.0; 95\% CI: 1.5-2.8, p < 0.001) in multivariate analysis [50], which is also confirmed (OR, 2.64; 95\% CI: 1.78-3.89, p $<0.01$ ) by another study [63]. And the correlation between risk of PE and cisplatin-based chemotherapy has been observed (HR, 1.51; 95\% CI: 1.12-2.36) [31]. Lung cancer chemotherapy agents such as cisplatin, carboplatin, gemcitabine and paclitaxel increase procoagulant activity on endothelial cells by TF decryption through a disulfide bond formation in a PDI-dependent (protein disulfide isomerase) mechanism [72], and could have a thrombogenic effect due to direct endothelial lesion [73].

Target drugs can cause PE, for example, bevacizumab, the monoclonal antibody to vascular endothelial growth factor (VEGF), is associated with development of $\mathrm{PE}$ in lung cancer patients particularly in patients with SCLC [74]. Plasminogen activator inhibitor (PAI-1) expression in tumors, plasma, and thrombi could contribute to the bevacizumab's prothrombotic effect in a mouse xenograft model of human lung carcinoma, which indicates the inhibition of PAI-1 as a therapeutic strategy for the prevention of bevacizumab-associated VTE is efficient [75].

\subsubsection{Central venous catheters (CVC)}

$\mathrm{CVC}$ is at high risk of $\mathrm{PE}$ in lung cancer patients (OR, 2.00; 95\% CI: 1.07-3.74, p = 0.03) whereas in multivariate analysis, the association seems to be weak (OR, 1.76; 95\% CI: 0.99-2.76, p = 0.09) [63].

\section{PE Treatment}

ESC (The European Society of Cardiology) recommends that low-molecular-weight heparin (LMWH) administered in the acute phase (except for high-risk PE) and continued over the first 3-6 months should be considered as first-line therapy in patients with cancer and acute PE [76]. And, chronic anticoagulation may consist of continuation of $\mathrm{LMWH}$, transition to vitamin $\mathrm{K}$ antagonist (VKA), or discontinuation of anticoagulation [76].

PE can be treated only with unfractionated heparin (UFH) sodium followed by warfarin if the diagnosis of PE was confirmed and start the treatment immediately after the first episode in patients after operation for lung cancer [77]. And, another study also verified such patients could be treated aggressively with anticoagulants with/without fibrinolytics or even with pulmonary embolectomy on cardiopulmonary bypass, without excessive risk of bleeding complications [46].

In addition, clinicians should pay attention on cancer embolus occurred in the process of metastasis of lung cancer cells [78] as the efficiency of anticoagulation or thrombolytic therapy is poor while chemotherapy may be efficient.

Little evidence is available for treatment of lung cancer-related PE with the new oral anticoagulants.

\section{The assessment of risk-benefit ratio}

During the course of anticoagulant therapy, the main safety outcome is hemorrhage (major bleeding and minor bleeding) whereas prevention of $\mathrm{PE}$ recurrence or progression is also vital. Therefore, to reassess the risk-benefit ratio of anticoagulant treatment is an efficient strategy for patients with lung cancer and PE. In the process of anticoagulant therapy (mean duration, 139 days), the rate of PE recurrences was slightly higher than the rate of major bleeding (14 vs. 11 per 100 patient-years) in patients with lung cancer and PE [79]. Another study also indicated that the rate of major bleeding was 3\% in lung cancer patients with PE receiving anticoagulation [42]. 
In addition, the use of argatroban in conjunction with activated clotting time monitoring should be effective without causing bleeding problems during the early stages after pulmonary resection for lung cancer [46]. Besides, venous filters should primarily be considered when anticoagulation is impossible due to hemorrhage; however, the risk of filter thrombosis in the absence of anticoagulation may be particularly high in cancer patients [76].

\section{Prognostic Significance}

The mean survival time in lung cancer patients with PE is remarkably shorter than those without PE $[7,8,50,52,58,63,66,80]$, even in lung cancer patients with PE who all received UFH intravenously or LMWH subcutaneously, followed by an oral anticoagulant, the survival time is still significantly shorter than only those [59]. Furthermore, patients with PE and lung cancer diagnosed concomitantly have also significantly shorter mean survival time compared with matched controls (110.5 vs. 183.5 days, $p=0.003)$, but those with PE diagnosed after the diagnosis of lung cancer have no this difference (312 vs. 477 days, $p=0.206$ ) [80]. Another study found that PE detected within 3 months after diagnosis of lung cancer was significantly associated with shorter mean survival (8.9 months vs. 22.5 months; HR, 1.5; 95\% CI: 1.1-2.0; after adjustment for gender, age, histology, and initial cancer stage) compared with remainder lung cancer patients [50].

Only for lung cancer patients with UPE, no receiving anticoagulation therapy has a 4.1 -fold (95\% CI, 2.3-7.6) increase in mortality compared to those having received anticoagulation therapy [50]. Compared to lung cancer patients with suspected PE (4.2 months [95\% CI, 2.6-5.8 months]), those with UPE [9.3 months (95\% CI, 5.7-13.0 months)] have higher median overall survival $(P=0.001)$, even when anticoagulation therapy is administered to $99 \%$ of suspected PE patients and $45 \%$ of UPE patients, respectively ( $\mathrm{P}<0.001$ using the Chi-square test) [50]. And, the remarkable difference in the overall survival between the two groups is still present (HR, 1.7; 95\% CI: 1.1-2.6) after adjustment for other prognostic factors such as cancer stage and performance status at the time of diagnosis of PE [50]. However, another study denied the difference, finding median survival was similar between suspected PE group (5.6 months) and unsuspected PE group (6.2 month) in univariate and multivariate analyses [42]. Although the two studies showed different consequences, we couldn't ignore the importance of UPE in lung cancer patients.

Mortality is ascending in lung cancer patients with PE even if most patients died of cancer progression [52, 59, 81], thereby when the clinical presentation and objective tests raise the suspicion of $\mathrm{PE}$ in an individual patient, clinicians should prompt further objective testing to confirm $\mathrm{PE}$, and we shouldn't relax our vigilance against UPE.

\section{Prophylaxis of Thrombotic Events}

\subsection{Prophylaxis for Surgery}

Prophylactic anticoagulation preferably as LMWH or low-dose unfractionated heparin (LDUH) or fondaparinux should be given to all patients who underwent surgical producers for cancer perioperatively, and continue at least for 7 to 10 days unless contraindication occur: a high risk for active bleeding [82]. And, it could be better to continue up to 4 weeks for these patients with high-risk features such as residual disease, obesity, or prior VTE [82].

In addition, in a study of patients with primary lung cancer patients undergoing lung resection, three eligibility criteria [1) For the operation day, LDUH 5,000 unit every 12 hours; if diffuse adhesion in the thoracic cavity was observed or intraoperative blood loss $>500 \mathrm{ml}$, discontinue LDUH administration. 2) For the postoperative period, LDUH 5,000 unit every 12 hours; if the postoperative bleeding was over 400 $\mathrm{ml}$ on the operation day or the patient's body weight was less than $40 \mathrm{~kg}$, LDUH 2,500 unit every 12 hours. 3) Discontinue anticoagulation until the day when the patient could walk around the floor] was introduced and the efficacy had been certified [83]. And, In a large multicenter trial, that low-dose heparin $(5,000$ units) administered 2 hours before incision and then every 8 hours postoperatively dramatically reduced the incidence of VTE [84].

Furthermore, the appropriate preoperative usage of heparin enables the standard surgical treatment of lung cancer patients with cardiovascular complications, so Notsuda et al. recommend the use of LMWH or LDUH as the antithrombotic agent before lung cancer surgery especially for those with cardiovascular complications [85].

Some studies also found that huisheng oral solution [HSOS, a traditional Chinese medicine preparation; $20 \mathrm{~mL}$, tid (three times a day)] and preoperative insertion of inferior vena cava filter (IVC filter) were of good safety profiles for prophylaxis of PE $[86,87]$.

\subsection{The Assessment of Risk-benefit Ratio for Anticoagulant Therapy}

Anticoagulant therapy significantly prolongs life expectance and decreases the risk of VTE for patients with non-advanced/limited lung cancer (risk ratio [RR], 1.30; 95\% CI: 1.03-1.65; $p=0.03)$, especially those with SCLC (RR, 1.21; 95\% CI: 1.07-1.38; $\mathrm{p}=0.003)$, but 
not in those with NSCLC $(p=0.78)$ [88]. Another study also found anticoagulation (LMWH, UFH, warfarin) showed a pooled mortality benefit, and no significant difference between LMWH and warfarin [89]. Furthermore, the clinical trials of anticoagulation in addition to chemotherapy suggested a survival benefit among patients with SCLC [90-92]. Therefore, anticoagulation is useful for prophylaxis of PE in lung cancer patients, especially in patients with limited SCLC, but it not only carries an intrinsic and clinical relevant risk of major bleeding but also is expensive [93, 94], implying the importance of assessment of risk-benefit ratio.

\subsubsection{Warfarin.}

Warfarin increased risk of bleeding in patients with lung cancer (RR, 5.14, 95\% CI: 1.66 to 15.94; $\mathrm{p}=$ 0.005) [88]. And, compared to LMWH and unfractionated heparin groups in lung cancer patients, the greatest odds of bleeding was found in the warfarin group (OR, 5.42; 95\% CI: 3.48-8.45) [89]. The estimate of warfarin for mortality in all SCLC was statistically significant at six months (RR, 0.69; 95\% CI: $0.50-0.96, p=0.028)$ but not at one year (RR, 0.88 ; 95\% CI: 0.77 to $1.01, \mathrm{p}=0.070)$, meanwhile, a significant increased risk of major bleeding (RR, 5.46; 95\% CI: 3.04-9.81, $\mathrm{p}<0.000001)$ and minor bleeding (RR, 4.01; 95\% CI: $1.30-12.42, \mathrm{p}=0.016$ ) has been obtained [95]. Furthermore, warfarin plus chemotherapy don't demonstrate the survival advantage in patients with SCLC because of the more warfarin-related deaths [96].

\subsubsection{Heparin.}

Primary prophylaxis with LMWH (at least for 6 weeks) reduces the incidence of PE in lung cancer patients [89], especially in those receiving chemotherapy $[97,98]$. In patients with limited SCLC, heparin including unfractionated heparin (UFH) and LMWH (prophylactic dose for at least 5 weeks) suggests a survival benefit (HR, 0.56; 95\% CI: $0.38-0.83, \mathrm{p}=0.004$ ) whereas no significant survival benefit is observed in patients with extensive SCLC or advanced lung cancer (HR, 0.80; 95\% CI: 0.60-1.06, p = 0.12) [99]. In addition, patients with NSCLC stage IV had a statistically significant reduction in VTE rate with LMWH (throughout induction chemotherapy) compared with placebo group $(3.5 \%$ vs. $10.2 \%$, OR, 0.32; 95\% CI: $0.09-0.98 ; p=0.032)$, in contrast, the stage III group receiving LMWH thromboprophylaxis did not reduce the incidence of VTE compared to placebo (5.7\% and $6.4 \%$, respectively) [100]. It's important that many studies found that increased risk of bleeding wasn't noted for heparin in lung cancer patients [88, $89,97,99]$, therefore heparin is a suitable choice for prophylaxis.

\section{Comment}

There is a significant relationship between lung cancer and PE, while very little references were known about PE and lung cancer. Furthermore, this relationship is further confused because respiratory distress in lung cancer patients is often attributed to pneumonia, disease progression, malignant pleural effusion or other complications, which may contribute to the high incidence of UPE (range 29.4\%-63\%). Characteristics of patients with lung cancer such as adenocarcinoma and the usage of anti-cancer drug are more prone to have a harboring PE. What's more, the incidence of PE may be underestimated with the decrease of the overall number of autopsies performed worldwide, especially for lung cancer patients of sudden death.

Anyway, studying based on the literature, the rates of PE in patients with lung cancer remain high across all patients with cancer, with an overall incidence frequency of $3.7 \%$. Of all, lung cancer patients receiving nonsurgical therapy have higher rate of $\mathrm{PE}$ compared with those only receiving surgical therapy $[5.0 \%$ (only nonsurgical), $2.5 \%$ (nonsurgical + surgical) vs. $1.6 \%$ ] and a high overall incidence of PE has also been found in RCTs (2.3\%). When lung cancer was diagnosed, many therapeutic interventions such as surgical series and nonoperative series were implemented according to the stage and histological type of lung cancer, which reflects the differences of occurrence of PE. For example, patients with advanced stages of cancer are not surgical candidates whereas they have higher risk for the development of PE. Besides, blood parameters such D-dimer, $\mathrm{PaO}_{2}$, and tumor markers (CEA, SCC, CYFRA21-1, NSE and ProGRP) etc. seem to be the predictors of $\mathrm{PE}$, and not less than 3 abnormal values in the five TMs [57] is the optimal cutoff value to assist the diagnosis of PE with both high sensitivity and specificity. Indeed, many risk factors of PE in lung cancer patients are correlative and promote the occurrence together in clinical work.

Although the treatment of PE has been more and more normative in lung cancer patients, when it occurs, survival time is significantly decreased. Especially, UPE has also a decreased survival time in lung cancer patients whereas we usually neglect it in clinical work, thereby whether objective testing for PE should be the routine testing in lung cancer patients need more studies to assess. According to scan some references, we could draw a conclusion that heparin seems superior to VKA for thrombotic prophylaxis, and prophylactic anticoagulant therapy benefit might be highest in patients with stage IV NSCLC or limited SCLC. Furthermore, we summarized the prophylactic anticoagulation for lung cancer and gave a 


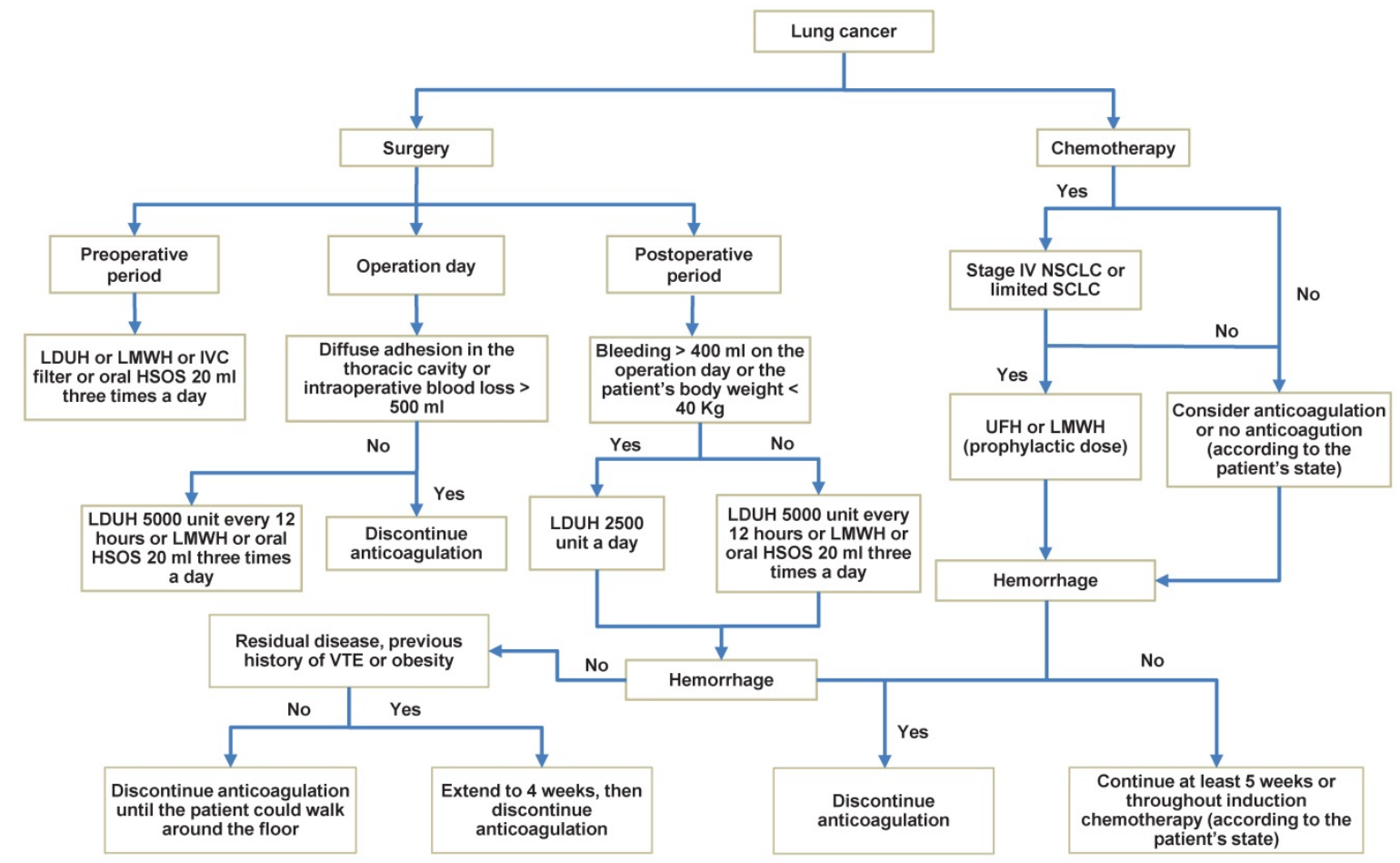

Fig. 2. Prophylactic anticoagulation in lung cancer patients. NOTE: When PE is confirmed in the process of prophylactic anticoagulation, treatment should be taken quickly. LDUH: low-dose unfractionated heparin; LMWH: lower-molecular-weight heparin; HSOS: huisheng oral solution; IVC filter: Inferior vena cava filter; UFH: unfractionated heparin.

recommendation (Fig. 2), of which the main safety outcome was hemorrhage (major bleeding and minor bleeding). However, such a recommendation, albeit plausible, has not been tested in randomized trials and needs further investigation.

\section{Future Recommendations}

Drug therapy of lung cancer seems to be a powerful risk factor for PE, however, thrombotic risk of every chemotherapeutic drug and targeted drug in lung cancer patients has not been studied extensively. In addition, new oral anticoagulants are very efficient in patients with PE, however, the efficiency of them in patients with cancer especially lung cancer has not been estimated. Notably, large, high quality outcome trials on the optimal prophylaxis and treatment of PE in lung cancer patients are lacking and the assessment for the safety of the new oral anticoagulants is also limited, which warrants further investigation.

In conclusion, this study demonstrated the association between lung cancer and PE, showing the high incidence of PE in lung cancer patients. When PE occurs, it could be fatal and affect survival, thereby, it is necessary for us to understand the risk factors and master its prophylaxis. As for treatment, the main safety outcome of anticoagulant therapy was hemorrhage, thereby risk assessment will remain the cornerstone of the PE therapeutic management. There is no doubt that selection of lung cancer patients for early diagnose or treatment of PE will probably be more efficient, which could increase mean survival time.

\section{Abbreviations}

TM: tumor marker; CEA: serum carcinoembryonic antigen; WBC: white blood cell; COPD: chronic obstructive pulmonary disease; PCA: procoagulant activity; TF: tissue factor; $\mathrm{F} 1+2$ : prothrombin fragment $1+2$; BMI: body mass index; SCC: squamous cell carcinoma antigen; CYFRA21-1: cytokeratin 19 fragment; NSE: neuron-specific enolase; ProGRP: progastrin-releasing peptide; TMs: tumor markers; LDUH: low-dose unfractionated heparin; LMWH: lower-molecular-weight heparin; HSOS: huisheng oral solution; IVC filter: Inferior vena cava filter; UFH: unfractionated heparin; NR: not reported; VTE: venous thromembolism; PE: pulmonary embolism; UPE: unsuspected pulmonary embolism; DVT: deep vein thrombosis; RCT: randomized controlled trial; NSCLC: non-small cell lung cancer; SCLC: small cell lung cancer; VKA: vitamin $\mathrm{K}$ antagonist; EGFR: epidermal growth factor receptor; KRAS: KRAS proto-oncogene, GTPase; ALK: ALK receptor tyrosine kinase; INTEM: Intrinsic pathway; EXTEM: extrinsic pathway; VATS: video-assisted thoracoscopic surgery; RAVTS: robotic-assisted video thoracoscopic surgery; AUC: area under curve; ROC: receiver operating 
characteristic; PDI: protein disulfide isomerase; PAI-1: plasminogen activator inhibitor; CVC: central venous catheters.

\section{Competing Interests}

The authors have declared that no competing interest exists.

\section{References}

1. Torre LA, Bray F, Siegel RL, Ferlay J, Lortet-Tieulent J, Jemal A. Global cancer statistics, 2012. CA Cancer J Clin. 2015; 65: 87-108.

2. Sorensen HT, Mellemkjaer L, Olsen JH, Baron JA. Prognosis of cancers associated with venous thromboembolism. N Engl J Med. 2000; 343: 1846-50.

3. Lee JE, Kim HR, Lee SM, Yim JJ, Yoo CG, Kim YW, et al. Clinical characteristics of pulmonary embolism with underlying malignancy. The Korean journal of internal medicine. 2010; 25: 66-70.

4. Wang H, Huang $\mathrm{Y}, \mathrm{Xu} \mathrm{CW}$, Lin L. Clinical analysis of tumor and non-tumor patients complicated with pulmonary embolism. Int J Clin Exp Med. 2015; 8: 18729-36.

5. Li G, Lu WX, Wang C. [Pulmonary embolism in cancer: clinical analysis of 60 cases]. Zhonghua Zhong Liu Za Zhi. 2009; 31: 550-3.

6. van Herk-Sukel MP, Shantakumar S, Penning-van Beest FJ, Kamphuisen PW, Majoor CJ, Overbeek LI, et al. Pulmonary embolism, myocardial infarction, and ischemic stroke in lung cancer patients: results from a longitudinal study. Lung. 2013; 191: 501-9.

7. Christensen TD, Vad H, Pedersen S, Hvas AM, Wotton R, Naidu B, et al. Venous thromboembolism in patients undergoing operations for lung cancer: a systematic review. The Annals of thoracic surgery. 2014; 97: 394-400.

8. Xu X, Yang H, Qiao L, Tan Z, Jin J, Jin Y, et al. [Clinical characteristic and outcomes of lung cancer patients with venous thromboembolism]. Zhonghua Yi Xue Za Zhi. 2014; 94: 2045-9.

9. Nichols L, Saunders R, Knollmann FD. Causes of death of patients with lung cancer. Archives of pathology \& laboratory medicine. 2012; 136: 1552-7.

10. Steuer CE, Behera M, Kim S, Patel N, Chen Z, Pillai R, et al. Predictors and outcomes of venous thromboembolism in hospitalized lung cancer patients: A Nationwide Inpatient Sample database analysis. Lung cancer. 2015; 88: 80-4.

11. Connolly GC, Dalal M, Lin J, Khorana AA. Incidence and predictors of venous thromboembolism (VTE) among ambulatory patients with lung cancer. Lung cancer. 2012; 78: 253-8.

12. Wehler T, Thomas M, Schumann C, Bosch-Barrera J, Vinolas Segarra N, Dickgreber NJ, et al. A randomized, phase 2 evaluation of the CHK1 inhibitor, LY2603618, administered in combination with pemetrexed and cisplatin in patients with advanced nonsquamous non-small cell lung cancer. Lung cancer. 2017; 108: 212-6.

13. Hirsch FR, Govindan R, Zvirbule Z, Braiteh F, Rittmeyer A, Belda-Iniesta C, et al. Efficacy and Safety Results From a Phase II, Placebo-Controlled Study of Onartuzumab Plus First-Line Platinum-Doublet Chemotherapy for Advanced Squamous Cell Non-Small-Cell Lung Cancer. Clinical lung cancer. 2017; 18: 43-9.

14. Levy A, Bardet E, Lacas B, Pignon JP, Adam J, Lacroix L, et al. A phase II open-label multicenter study of gefitinib in combination with irradiation followed by chemotherapy in patients with inoperable stage III non-small cell lung cancer. Oncotarget. 2017; 8: 15924-33.

15. Goss G, Tsai CM, Shepherd FA, Bazhenova L, Lee JS, Chang GC, et al. Osimertinib for pretreated EGFR Thr790Met-positive advanced non-small-cell lung cancer (AURA2): a multicentre, open-label, single-arm, phase 2 study. Lancet Oncol. 2016; 17: 1643-52.

16. $\mathrm{Hu} \mathrm{W}$, Zhang $\mathrm{Z}$. A phase II clinical study of using nab-paclitaxel as second-line chemotherapy for Chinese patients with advanced non-small cell lung cancer. Med Oncol. 2015; 32: 498.

17. Karavasilis V, Kosmidis P, Syrigos KN, Mavropoulou P, Dimopoulos MA, Kotoula V, et al. Docetaxel and intermittent erlotinib in patients with metastatic Non-Small Cell Lung Cancer; a phase II study from the Hellenic Cooperative Oncology Group. Anticancer Res. 2014; 34: 5649-55.

18. Dingemans AM, Bootsma G, van Baardwijk A, Reymen B, Wanders R, Brans B, et al. A phase I study of concurrent individualized, isotoxic accelerated radiotherapy and cisplatin-vinorelbine-cetuximab in patients with stage III non-small-cell lung cancer. J Thorac Oncol. 2014; 9: 710-6.

19. Powell SF, Beitinjaneh A, Tessema M, Bliss RL, Kratzke RA, Leach J, et al. Phase II study of topotecan and bevacizumab in advanced, refractory non--small-cell lung cancer. Clinical lung cancer. 2013; 14: 495-501.

20. Mountzios G, Emmanouilidis C, Vardakis N, Kontopodis E, Hatzidaki D, Popis E, et al. Paclitaxel plus bevacizumab in patients with chemoresistant relapsed small cell lung cancer as salvage treatment: a phase II multicenter study of the Hellenic Oncology Research Group. Lung cancer. 2012; 77: 146-50.

21. Crino L, Dansin E, Garrido P, Griesinger F, Laskin J, Pavlakis N, et al. Safety and efficacy of first-line bevacizumab-based therapy in advanced non-squamous non-small-cell lung cancer (SAiL, MO19390): a phase 4 study. Lancet Oncol. 2010; 11: 733-40.
22. Altorki N, Lane ME, Bauer T, Lee PC, Guarino MJ, Pass $\mathrm{H}$, et al. Phase II proof-of-concept study of pazopanib monotherapy in treatment-naive patients with stage I/II resectable non-small-cell lung cancer. J Clin Oncol. 2010; 28: 3131-7.

23. Levitan N, Dowlati A, Craffey M, Tahsildar H, MacKay W, McKenney J, et al. A brief intensive cisplatin-based outpatient chemotherapy regimen with filgrastim and megestrol acetate support for advanced non-small cell lung cancer: results of a phase II trial. Lung cancer. 1998; 22: 227-34.

24. Fanucchi M, Glaspy J, Crawford J, Garst J, Figlin R, Sheridan W, et al. Effects of polyethylene glycol-conjugated recombinant human megakaryocyte growth and development factor on platelet counts after chemotherapy for lung cancer. N Engl J Med. 1997; 336: 404-9.

25. Moon MH, Beck KS, Moon YK, Park JK, Sung SW. Incidence and clinical features of the incidentally found vascular stump thrombus during routine follow up after oncologic lung surgery. PloS one. 2017; 12: e0185140.

26. Glover J, Velez-Cubian FO, Toosi K, Ng E, Moodie CC, Garrett JR, et al. Perioperative outcomes and lymph node assessment after induction therapy in patients with clinical N1 or N2 non-small cell lung cancer. Journal of thoracic disease. 2016; 8: 2165-74.

27. Mungo B, Hooker CM, Ho JS, Yang SC, Battafarano RJ, Brock MV, et al. Robotic Versus Thoracoscopic Resection for Lung Cancer: Early Results of a New Robotic Program. J Laparoendosc Adv Surg Tech A. 2016; 26: 243-8.

28. Michelsen L, Sorensen JB. Platinum-Vinorelbine Induction Chemotherapy plus Bevacizumab With and Without Pemetrexed Switch Maintenance in Advanced NSCLC. Anticancer Res. 2015; 35: 6255-9.

29. Sandri A, Papagiannopoulos K, Milton R, Kefaloyannis E, Chaudhuri N, Poyser E, et al. Major morbidity after video-assisted thoracic surgery lung resections: a comparison between the European Society of Thoracic Surgeons definition and the Thoracic Morbidity and Mortality system. Journal of thoracic disease. 2015; 7: 1174-80.

30. Cukic V, Ustamujic A. Lung Cancer And Pulmonary Thromboembolism Materia socio-medica. 2015; $27: 351-3$.

31. Verso M, Chiari R, Mosca S, Franco L, Fischer M, Paglialunga L, et al. Incidence of $\mathrm{Ct}$ scan-detected pulmonary embolism in patients with oncogene-addicted, advanced lung adenocarcinoma. Thrombosis research. 2015; 136: 924-7.

32. Zhang Y, Yang Y, Chen W, Guo L, Liang L, Zhai Z, et al. Prevalence and associations of VTE in patients with newly diagnosed lung cancer. Chest. 2014; 146: 650-8

33. Mellema WW, van der Hoek D, Postmus PE, Smit EF. Retrospective evaluation of thromboembolic events in patients with non-small cell lung cancer treated with platinum-based chemotherapy. Lung cancer. 2014; 86: 73-7.

34. Wang Z, Zhang J, Cheng Z, Li X, Wang Z, Liu C, et al. Factors affecting major morbidity after video-assisted thoracic surgery for lung cancer. The Journal of surgical research. 2014; 192: 628-34.

35. Kadlec B, Skrickova J, Merta Z, Dusek L, Jarkovsky J. The incidence and predictors of thromboembolic events in patients with lung cancer. TheScientificWorldJournal. 2014; 2014: 125706.

36. Nguyen NP, Shen W, Kratz S, Vock J, Vos P, Vincent VH, et al. Feasibility of tomotherapy-based image-guided radiotherapy for small cell lung cancer. Front Oncol. 2013; 3: 289

37. Yu DP, Han $Y$, Zhao OY, Liu ZD. Pulmonary lobectomy combined with pulmonary arterioplasty by complete video-assisted thoracic surgery in patients with lung cancer. Asian Pac J Cancer Prev. 2013; 14: 6061-4.

38. Luo J, Chen B, Jiang S, Zhou SW. [Interventional therapy for lung cancer patients with superior vena cava syndrome]. Zhonghua Zhong Liu Za Zhi. 2013; 35: 627-31

39. Connolly GC, Menapace L, Safadjou S, Francis CW, Khorana AA. Prevalence and clinical significance of incidental and clinically suspected venous thromboembolism in lung cancer patients. Clinical lung cancer. 2013; 14: 713-8.

40. Crolow C, Samulowski M, Blum T, Kollmeier J, Schönfeld N, Bittner R, et al. Häufigkeit thromboembolischer Komplikationen bei Patienten mit Lungenkarzinom. 2013

41. Dhakal B, Eastwood D, Sukumaran S, Hassler G, Tisol W, Gasparri M, et al. Morbidities of lung cancer surgery in obese patients. The Journal of thoracic and cardiovascular surgery. 2013; 146: 379-84.

42. Shinagare AB, Okajima Y, Oxnard GR, DiPiro PJ, Johnson BE, Hatabu H, et al. Unsuspected pulmonary embolism in lung cancer patients: Comparison of linical characteristics and outcome with suspected pulmonary embolism. Lung cancer. 2012; 78: 161-6.

43. Dentali F, Malato A, Ageno W, Imperatori A, Cajozzo M, Rotolo N, et al. Incidence of venous thromboembolism in patients undergoing thoracotomy for lung cancer. The Journal of thoracic and cardiovascular surgery. 2008; 135: 705-6.

44. Behrendt $\mathrm{CE}$, Ruiz RB. Venous thromboembolism among patients with advanced lung cancer randomized to prinomastat or placebo, plus chemotherapy. Thromb Haemost. 2003; 90: 734-7.

45. Gharagozloo F, Tempesta B, Margolis M, Alexander EP. Video-assisted thoracic surgery lobectomy for stage I lung cancer. The Annals of thoracic surgery. 2003; 76: 1009-14; discussion 14-5.

46. Sakuragi T, Sakao Y, Furukawa K, Rikitake K, Ohtsubo S, Okazaki Y, et al. Successful management of acute pulmonary embolism after surgery for lung cancer. European journal of cardio-thoracic surgery : official journal of the European Association for Cardio-thoracic Surgery. 2003; 24: 580-7. 
47. Suntharalingam M, Sonett JR, Haas ML, Doyle LA, Hausner PF, Schuetz J, et al. The use of concurrent chemotherapy with high-dose radiation before surgical resection in patients presenting with apical sulcus tumors. Cancer J. 2000; 6: 365-71.

48. Tavecchio L, Ravasi G, Bedini AV, Gramaglia A, Milani F. Surgery after radiochemotherapy for stage III lung cancer: postoperative complications and late results. Journal of surgical oncology. 1994; 56: 2-6.

49. Thomas P, Magnan PE, Moulin G, Giudicelli R, Fuentes P. Extended operation for lung cancer invading the superior vena cava. European journal of cardio-thoracic surgery : official journal of the European Association for Cardio-thoracic Surgery. 1994; 8: 177-82.

50. Sun JM, Kim TS, Lee J, Park YH, Ahn JS, Kim H, et al. Unsuspected pulmonary emboli in lung cancer patients: the impact on survival and the significance of anticoagulation therapy. Lung cancer. 2010; 69: 330-6.

51. Numico G, Garrone O, Dongiovanni V, Silvestris N, Colantonio I, Di Costanzo $\mathrm{G}$, et al. Prospective evaluation of major vascular events in patients with nonsmall cell lung carcinoma treated with cisplatin and gemcitabine. Cancer. 2005; 103: 994-9.

52. Lee JW, Cha SI, Jung CY, Choi WI, Jeon KN, Yoo SS, et al. Clinical course of pulmonary embolism in lung cancer patients. Respiration; international review of thoracic diseases. 2009; 78: 42-8.

53. Davies NA, Harrison NK, Sabra A, Lawrence MJ, Noble S, Davidson SJ, et al. Application of ROTEM to assess hypercoagulability in patients with lung cancer. Thrombosis research. 2015; 135: 1075-80.

54. Koldas M, Gumus M, Seker M, Seval H, Karaoglu H, Dane F, et al. Thrombin-Activatable Fibrinolysis Inhibitor Levels in Patients with Non-Small-Cell Lung Cancer. Clinical lung cancer. 2008; 9: 112-5.

55. Keller T, Salge U, Konig H, Dodt J, Heiden M, Seitz R. Tissue factor is the only activator of coagulation in cultured human lung cancer cells. Lung cancer. 2001; 31: 171-9.

56. Ma R, Bi Y, Kou J, Zhou J, Shi J. Enhanced procoagulant activity of platelets after chemotherapy in non-small cell lung cancer. Cancer biology \& therapy. 2017: 1-8

57. Xiong $\mathrm{W}, \mathrm{Zhao} \mathrm{Y}, \mathrm{Xu} \mathrm{M}, \mathrm{Guo}$ J, Pudasaini B, Wu X, et al. The relationship between tumor markers and pulmonary embolism in lung cancer. Oncotarget. 2017; 8: 41412-21.

58. Sun W, Wang H, Wen Z, Ma N, Xiao Y, Ma L, et al. [Clinical characteristics of lung cancer complicated with pulmonary embolism]. Zhonghua Jie $\mathrm{He} \mathrm{He} \mathrm{Hu}$ Xi Za Zhi. 2016; 39: 198-202

59. Ma L, Wen Z. Risk factors and prognosis of pulmonary embolism in patients with lung cancer. Medicine. 2017; 96: e6638.

60. Chew HK, Davies AM, Wun T, Harvey D, Zhou H, White RH. The incidence of venous thromboembolism among patients with primary lung cancer. Journal of thrombosis and haemostasis : JTH. 2008; 6: 601-8.

61. Cushman M, Tsai AW, White RH, Heckbert SR, Rosamond WD, Enright $\mathrm{P}$, et al. Deep vein thrombosis and pulmonary embolism in two cohorts: the longitudinal investigation of thromboembolism etiology. The American journal of medicine. 2004; 117: 19-25.

62. Papageorgiou C, Vandreden P, Marret E, Bonnet F, Robert F, Spyropoulos A, et al. Lobectomy and postoperative thromboprophylaxis with enoxaparin improve blood hypercoagulability in patients with localized primary lung adenocarcinoma. Thrombosis research. 2013; 132: 584-91.

63. Wang J, Zhou W, Xu L, Yang M, Meng L, Fan W, et al. [Risk factors and prognosis of lung cancer combined with pulmonary embolism]. Zhongguo fei ai za zhi $=$ Chinese journal of lung cancer. 2011; 14: 780-4

64. Rong Y, Post DE, Pieper RO, Durden DL, Van Meir EG, Brat DJ. PTEN and hypoxia regulate tissue factor expression and plasma coagulation by glioblastoma. Cancer Res. 2005; 65: 1406-13.

65. Yu JL, May L, Lhotak V, Shahrzad S, Shirasawa S, Weitz JI, et al. Oncogenic events regulate tissue factor expression in colorectal cancer cells: implications for tumor progression and angiogenesis. Blood. 2005; 105: 1734-41.

66. Li N, Wang Y. [Clinical features in 23 lung cancer patients complicated with pulmonary thromboembolism]. Zhongguo fei ai za zhi $=$ Chinese journal of lung cancer. 2014; 17: 254-9.

67. Thomas PA, Berbis J, Falcoz PE, Le Pimpec-Barthes F, Bernard A, Jougon J, et al. National perioperative outcomes of pulmonary lobectomy for cancer: the influence of nutritional status. European journal of cardio-thoracic surgery : official journal of the European Association for Cardio-thoracic Surgery. 2014; 45: 652-9; discussion 9.

68. Gale AJ, Gordon SG. Update on tumor cell procoagulant factors. Acta Haematol. 2001; 106: 25-32.

69. Wang Z, Fu J, Diao D, Dang C. Plasma D-dimer level in the perioperative period in non-small-cell lung cancer. Thoracic cancer. 2011; 2: 207-12.

70. Kostecka IA, Haponowicz B, Sienkiewicz P, Wierzbicka M. [Concentration of prothrombin fragments $1+2(\mathrm{~F} 1+2)$ and thrombin-antithrombin III complexes (TAT)in patients with primary non-small cell lung cancer, before and after resection]. Przegl Lek. 2000; 57: 451-4

71. Kalweit G, Huwer H, Volkmer I, Petzold T, Gams E. Pulmonary embolism: a frequent cause of acute fatality after lung resection. European journal of cardio-thoracic surgery : official journal of the European Association for Cardio-thoracic Surgery. 1996; 10: 242-6; discussion 6-7.

72. Lysov Z, Swystun LL, Kuruvilla S, Arnold A, Liaw PC. Lung cancer chemotherapy agents increase procoagulant activity via protein disulfide isomerase-dependent tissue factor decryption. Blood coagulation \& fibrinolysis : an international journal in haemostasis and thrombosis. 2015; 26: $36-45$

73. Marinho FC, Takagaki TY. Hypercoagulability and lung cancer. J Bras Pneumol. 2008; 34: 312-22

74. Barber NA, Ganti AK. Pulmonary toxicities from targeted therapies: a review. Targeted oncology. 2011; 6: 235-43.

75. Chen N, Ren M, Li R, Deng X, Li Y, Yan K, et al. Bevacizumab promotes venous thromboembolism through the induction of PAI-1 in a mouse xenograft model of human lung carcinoma. Molecular Cancer. 2015; 14

76. Konstantinides SV, Torbicki A, Agnelli G, Danchin N, Fitzmaurice D, Galie N, et al. 2014 ESC guidelines on the diagnosis and management of acute pulmonary embolism. European heart journal. 2014; 35: 3033-69, 69a-69k

77. Miyoshi K, Okumura N, Kokado Y, Matsuoka T, Kameyama K, Nakagawa T. [Pulmonary thromboembolism in patients after surgery for pulmonary malignant tumor]. Kyobu Geka. 2006; 59: 821-5.

78. Siegel Y, Kuker R, Danton G, Gonzalez J. Occult Lung Cancer Occluding a Pulmonary Vein with Suspected Venous Infarction, Mimicking Pneumonia and a Pulmonary Embolus. The Journal of emergency medicine. 2016; 51: e11-4.

79. Mahé I, Chidiac J, Bertoletti L, Font C, Trujillo-Santos J, Peris M, et al. The Clinical Course of Venous Thromboembolism May Differ According to Cancer Site. The American journal of medicine. 2017; 130: 337-47.

80. Chuang YM, Yu CJ. Clinical characteristics and outcomes of lung cancer with pulmonary embolism. Oncology. 2009; 77: 100-6.

81. Ger LP, Hsu WL, Chen KT, Chen CJ. Risk factors of lung cancer by histological category in Taiwan. Anticancer Res. 1993; 13: 1491-500.

82. Lyman GH, Kuderer NM, American Society of Clinical O. Prevention and treatment of venous thromboembolism among patients with cancer: the American Society of Clinical Oncology Guidelines. Thrombosis research. 2010; 125 Suppl 2: S120-7.

83. Muraoka M, Mochinaga $K$, Sengyoku $H$, Ryu $C$, Ikuta $Y$, Tabuchi $S$, et al. [Efficacy and safety of administration of low-dose unfractionated heparin (LDUH) for the prevention of pulmonary thromboembolism after surgery for lung cancer; the long term outcome]. Kyobu Geka. 2013; 66: 93-100.

84. Prevention of fatal postoperative pulmonary embolism by low doses of heparin. An international multicentre trial. Lancet. 1975; 2: 45-51.

85. Notsuda H, Hoshikawa Y, Sakurada A, Endo C, Maeda S, Watanabe T, et al. [Perioperative management of lung cancer patients with cardiovascular complications]. Kyobu Geka. 2015; 68: 255-9.

86. Patel A, Anraku M, Darling GE, Shepherd FA, Pierre AF, Waddell TK, et al. Venous thromboembolism in patients receiving multimodality therapy for thoracic malignancies. The Journal of thoracic and cardiovascular surgery. 2009; 138: 843-8

87. Yang X, Zhang H, Kong F, Wang G, Gu Q, Zhao Z, et al. Effect of Huisheng oral solution on coagulation function in perioperative period in patients with primary lung cancer. Journal of thoracic disease. 2017; 9: 1891-902.

88. Zhang J, Zhang Y-L, Ma K-X, Qu J-M. Efficacy and safety of adjunctive anticoagulation in patients with lung cancer without indication for anticoagulants: a systematic review and meta-analysis. Thorax. 2013; 68: $442-50$.

89. Fuentes HE, Oramas DM, Paz LH, Casanegra AI, Mansfield AS, Tafur AJ. Meta-analysis on anticoagulation and prevention of thrombosis and mortality among patients with lung cancer. Thrombosis research. 2017; 154: 28-34.

90. Zacharski LR, Henderson WG, Rickles FR, Forman WB, Cornell CJ, Jr., Forcier $\mathrm{RJ}$, et al. Effect of warfarin anticoagulation on survival in carcinoma of the lung, colon, head and neck, and prostate. Final report of VA Cooperative Study \#75. Cancer. 1984; 53: 2046-52.

91. Altinbas M, Coskun HS, Er O, Ozkan M, Eser B, Unal A, et al. A randomized clinical trial of combination chemotherapy with and without low-molecular-weight heparin in small cell lung cancer. Journal of thrombosis and haemostasis : JTH. 2004; 2: 1266-71.

92. Lebeau B, Chastang C, Brechot JM, Capron F, Dautzenberg B, Delaisements C, et al. Subcutaneous heparin treatment increases survival in small cell lung cancer. "Petites Cellules" Group. Cancer. 1994; 74: 38-45.

93. Attaran S, Somov P, Awad WI. Randomised high- and low-dose heparin prophylaxis in patients undergoing thoracotomy for benign and malignant disease: effect on thrombo-elastography. European journal of cardio-thoracic surgery : official journal of the European Association for Cardio-thoracic Surgery 2010 ; 37 : 1384-90.

94. Tesselaar ME, Osanto S. Risk of venous thromboembolism in lung cancer. Curr Opin Pulm Med. 2007; 13: 362-7.

95. Akl EA, Kamath G, Kim SY, Yosuico V, Barba M, Terrenato I, et al. Oral anticoagulation for prolonging survival in patients with cancer. Cochrane Database Syst Rev. 2007: CD006466.

96. Chahinian AP, Propert KJ, Ware JH, Zimmer B, Perry MC, Hirsh V, et al. A randomized trial of anticoagulation with warfarin and of alternating chemotherapy in extensive small-cell lung cancer by the Cancer and Leukemia Group B. J Clin Oncol. 1989; 7: 993-1002.

97. Ben-Aharon I, Stemmer SM, Leibovici L, Shpilberg O, Sulkes A, Gafter-Gvili A. Low molecular weight heparin (LMWH) for primary thrombo-prophylaxis in patients with solid malignancies - systematic review and meta-analysis. Acta Oncologica. 2014; 53: 1230-7.

98. Verso M, Gussoni G, Agnelli G. Prevention of venous thromboembolism in patients with advanced lung cancer receiving chemotherapy: a combined 
analysis of the PROTECHT and TOPIC-2 studies. Journal of thrombosis and haemostasis : JTH. 2010; 8: 1649-51.

99. Akl EA, van Doormaal FF, Barba M, Kamath G, Kim SY, Kuipers S, et al.

Parenteral anticoagulation may prolong the survival of patients with limited small cell lung cancer: a Cochrane systematic review. J Exp Clin Cancer Res. 2008; $27: 4$.

100. Aikens GB, Rivey MP, Hansen CJ. Primary venous thromboembolism prophylaxis in ambulatory cancer patients. The Annals of pharmacotherapy. 2013; 47: 198-209. 